\title{
Seasonal grazing affects soil physical properties of a montane riparian community
}

\author{
MELINDA A. WHEELER, M.J. TRLICA, GARY W. FRASIER AND J.D. REEDER
}

Authors are former Graduate Research Assistant and Professor, Rangeland Ecosystem Science, Colorado State University, Fort Collins, Colo. 80523, and Research Scientists, respectively, USDA-ARS, Crops Research Laboratory, 1701 Center Street, Fort Collins, Colo., 80526.

\begin{abstract}
The effects of seasonal grazing treatments (early spring and late summer) on soil physical properties were studied in a montane riparian ecosystem in northern Colorado. Infiltration rates and bulk density were used as primary indicators of responses to a 1-time heavy grazing event on previously protected paddocks. Soil bulk density, porosity, gravimetric water content, organic carbon concentration and texture were measured at $0-5 \mathrm{~cm}, 5-10$ $\mathrm{cm}$, and 10-15 cm depths to determine how these parameters affected infiltration rates. Assessment of initial changes and subsequent recovery of the soil properties in response to the grazing treatments was conducted by measuring these parameters before each grazing event and at 4 time periods following the grazing event. Few differences between spring or late summer grazing periods on soil physical properties were found. A stepwise multiple regression model for infiltration rate based on soil physical properties yielded a low $\mathbf{R}^{2}(0.31)$, which indicated much unexplained variability in infiltration. However, infiltration rates declined significantly and bulk density increased at the $5-10 \mathrm{~cm}$ depth and 10-15 cm depth in grazed plots immediately following grazing, but the highly organic surface layer $(0-5 \mathrm{~cm})$ had no significant compaction. Infiltration rates and soil bulk densities returned to pre-disturbed values within 1 year after grazing events, suggesting full hydrologic recovery. This recovery may be related to frequent freeze-thaw events and high organic matter in soils.
\end{abstract}

Key Words: Compaction, infiltration, soil bulk density, porosity, recovery

Use of mountainous riparian zones has been under increased scrutiny because of heightened awareness of their economical and ecological importance, as well as increased multiple use conflicts (Johnson et al. 1985). Improper management of many riparian areas has resulted in degradation of habitat for fish, wildlife and vegetation (Armour et al. 1994). Chaney et al. (1990) indicated that most of the degradation has been caused by improper cattle management. Livestock grazing in Western riparian zones has

Research was funded by the USDA-Rangeland Grants Program and Colorado State University Agricultural Experiment Station.

The authors would like to thank Gary Richardson for assistance with the statistical analysis

Manuscript accepted 13 Mar. 01

\section{Resumen}

Se estudiaron los efectos de tratamientos de apacentamiento estacional (inicios de primavera y fines del verano) en las propiedades físicas del suelo de un ecosistema ribereño montano del norte de Colorado. Las tasas de infiltración y densidad aparente se utilizaron como indicadores principales de la respuesta a un evento de apacentamiento fuerte realizado una vez en potreros previamente protegidos. La densidad parente del suelo, la porosidad, el contenido gravimétrico de agua, la concentración de carbón orgánico y la textura se midieron a profundidades de $0-5 \mathrm{~cm}, 5-10 \mathrm{~cm}$ y 10-15 $\mathrm{cm}$ para determinar como estos parámetros afectaron las tasas de infiltración. La evaluación de los cambios iniciales y la recuperación subsecuente de las propiedades del suelo en respuesta a los tratamientos de apacentamiento se condujo midiendo estos parámetros antes y después de cada evento de apacentamiento y en 4 periodos de tiempo después del evento de apacentamiento. Se encontraron pocas diferencias en las propiedades del suelo entre los periodos de apacentamiento de primavera y finales verano. El modelo de regresión múltiple para la tasa de infiltración, basado en las propiedades físicas del suelo, produjo una $R^{2}$ baja $(0.31)$, la cual indico mucha de la variabilidad inexplicada en la infiltración. Sin embargo, inmediatamente después del apacentamiento, en las parcelas apacentadas, las tasas de infiltración disminuyeron significativamente y la densidad aparente se incrementó en las profundidades de $5-10 \mathrm{~cm}$ y $10-15 \mathrm{~cm}$, pero la capa superficial altamente orgánica $(0-5 \mathrm{~cm})$ no tuvo una compactación significativa. Las tasas de infiltración y la densidad aparente regresaron a los valores pre-disturbio dentro de un año después de los eventos de apacentamiento, sugiriendo una recuperación hidrológica total. Esta recuperación puede estar relacionada a los frecuentes eventos de congelación-descongelación y al alto contenido de materia orgánica de los suelos.

led to degradation of soil physical characteristics (Clary 1995), which in turn can lead to altered hydrologic properties (Bryant et al. 1972), increased sediment production (Warren et al. 1986b), and a decline in vegetation productivity and vigor (Dadkhah and Gifford 1980, Leininger and Trlica 1986).

Although some literature is available on the effects of cattle trampling on soil compaction and infiltration for upland rangelands (Warren et al. 1986a,1986b, Abdel-Magid et al. 1987a, $1987 b$ ), riparian soils generally possess more organic matter than upland soils and may therefore react differently to grazing. Little 
quantitative information is available describing how soils and infiltration in riparian areas respond to activities in different seasons (Tierney 1992), or on how quickly soils recover from changes that result from grazing livestock (Bohn and Buckhouse 1985, Warren et al. 1986b, Tierney 1992, Clary 1995). Specifically, timing of grazing and length of rest periods have been indicated as areas where further investigation is needed to help determine best management practices (Gifford and Hawkins 1978, Warren et al. 1986a). A major concern is how season of grazing, with variations in soil conditions, can affect water infiltration. If infiltration is adversely affected, consequences may include altered groundwater recharge (Gifford and Hawkins 1978), increased surface runoff and evaporation (Gamougoun et al. 1984), and reduced vegetation production and vigor (Leininger and Trlica 1986).

The objectives of this study were to determine how cattle grazing during different seasons might affect hydrological and physical characteristics of riparian soils. Knowledge gained should help to develop strategies to reduce grazing impacts and provide additional information as to the time required for riparian soils to recover from previous grazing. If recovery rates of soil properties after grazing are known, then better management techniques for these areas might be developed to reduce physical impacts that large animals have on these riparian ecosystems.

\section{Methods and Materials}

\section{Study Location and Site Description}

The study area was along Sheep Creek, a C1 stream (Rosgen 1994) that is located $80 \mathrm{~km}$ northwest of Fort Collins, Colo. The area is within the Roosevelt National Forest at an approximate elevation of $2,500 \mathrm{~m}$. The area had been severely overgrazed in the early part of the century, and was excluded from livestock grazing in 1956 by the Forest Service for resource recovery as well as research reasons. The major soil in the study area is a Fluvaquent, located in flood plains, low terraces and bottom lands in the area. The water table is commonly at a depth of less than $30 \mathrm{~cm}$ immediately following the spring melt. Gravimetric water content was often greater than $100 \%$ at the study site. The texture of the surface and underlying layers are extremely variable as a result of repeated flooding and range from sandy loam to clay loam. The soil profile is commonly stratified with thin layers of sand or clay. There was often a highly organic peat layer over $20 \mathrm{~cm}$ thick in sedge riparian communities. The vegetation community consisted of willows (primarily Salix planifolia, Pursh) that dominated the overstory, with Kentucky bluegrass (Poa pratensis, L.) water sedge (Carex aquatilus, Wahlenberg), beaked sedge (Carex rostrata, Boott), tufted hairgrass (Deschampsia caespitosa, (L)) and dandelion (Taraxacum officinale, G.H. Weber) as major components of the herbacious understory (Schulz and Leininger 1990, Popolizio et al. 1994). Similar riparian areas have been described in Montana (Marcuson, 1977), Oregon (Roath and Kruger 1982), Utah (Platts and Nelson 1989), and Wyoming (Costello 1944).

\section{Experimental Design}

A randomized complete block design with a factorial arrangement of treatments was used. Treatments involved 2 grazing strategies (grazed and control) and 2 seasons of grazing (early spring and late summer). Three replicated plots (paddocks) approximately $1 / 4$ ha in size for each grazing treatment and season of grazing were selected for similar traits of aspect, slope, vegetation community composition and soil type. The treatments were randomly applied to paddocks in a one-time, seasonal heavy grazing event where 60 to $75 \%$ of the herbacious vegetation was utilized (Pelster et al. 1996). Three ungrazed paddocks within the study area were used as a control. Six steers were put on the spring grazed plots beginning 30 June 1995, and grazing began on 8 September 1995 for summer grazed plots. The steers grazed in the plots for 4 to 5 days to reach the desired level of utilization.

Three random samples of soil bulk density were obtained and infiltration rates measured along $12 \mathrm{~m}$ transects within each of the 4 treatment combinations. Treatments were repeatedly sampled for 5 sampling periods (immediately before grazing, immediately after grazing, 2 weeks after grazing, 4 weeks after grazing, and 1 year after grazing).

Data were statistically analyzed with SAS programs (SAS 1996). Two analysis of variance (ANOVA) tests were used to determine if differences $(p<0.10)$ existed among grazing strategies, seasons of grazing, and repeated sample collections through time and all of their interactions. Soil bulk density and infiltration rates were the response variables. Data for the first time period were used as a covariate in an ANOVA model for infiltration and adjusted for the variability in initial conditions of the study because the first sample period before grazing began could not be included in the model as a grazing treatment effect. The use of the first time period as a covariate for the ANOVA model for bulk density was not appropriate because a significant time of sampling $\mathrm{x}$ grazing treatment interaction existed. Additionally, to determine immediate effects of grazing, an ANOVA was conducted to determine if differences existed for infiltration rates and bulk density between pre-grazed conditions and immediately after grazing. An ANOVA was also used to determine if differences were evident in infiltration rates and bulk density between pre-grazed conditions and soil conditions 1 year later to ascertain whether recovery occurred.

Stepwise multiple regression analyses were performed to determine if some easily measured soil physical properties might be used as predictors for changes in bulk density and infiltration rates. These properties included gravimetric water content, organic carbon concentration, soil texture, and time of sampling as possible predictors for bulk density. These same properties at 3 soil depths, plus bulk density and porosity were used as possible predictors for infiltration rates.

\section{Soil Parameters}

Soil characteristics of bulk density, infiltration rate, porosity, aggregate stability and gravimetric water content were assessed before steers were introduced into paddocks. Samples from soil depths of $0-5,5-10$ and $10-15 \mathrm{~cm}$ were individually analyzed for all parameters except infiltration rate. Soil organic $\mathrm{C}$ and $\mathrm{N}$ and soil texture were also assessed at the 3 depths for each plot to determine how these parameters might affect water infiltration rates and bulk density. Data for porosity, gravimetric water content, bulk density, aggregate stability and infiltration were collected again after animals had been removed from each plot. Samples from control plots were collected simultaneously with the grazed plots. Sampling was repeated after 2 weeks, 1 month, and 1 year after the grazing treatments to assess recovery of various soil characteristics.

\section{Sample Collection}

Soil samples were collected by the core method (Blake and Hartge 1986) to determine bulk density, porosity, gravimetric water content and aggregate stability at random locations on each of three, $12 \mathrm{~m}$ 
transects within each paddock on each sampling date. Three soil samples per paddock (1 sample per transect) were taken at each depth increment $(0-5,5-10$, and $10-15 \mathrm{~cm}$ ) for evaluation of bulk density, porosity and gravimetric water content. Two additional soil samples were collected along each transect and composited by depth increment for aggregate stability determination.

Infiltration rate was measured with a double ring falling head infiltrometer, which has been shown to give good comparative information for an area (Branson et al. 1981, Bouwer 1986). The inner ring was $25 \mathrm{~cm}$ in diameter, while the outer ring had a diameter of $50 \mathrm{~cm}$ to provide a hydraulic barrier to create one-dimensional flow. The outer ring was $3 \mathrm{~mm}$ thick and made of steel, while the inner ring was PVC pipe with a beveled cutting edge to minimize disturbance to the soil surface. Infiltration rates were assessed at 0,15 , $30,45,60,75$, and $90 \mathrm{~min}$. intervals. Equilibrium infiltration rates were derived from the last $15 \mathrm{~min}$. interval (Smith and Leopold 1941) and used to approximate saturated hydraulic conductivity for statistical analysis. Infiltration measurements were determined at 2 random locations along each of the 3 transects within each paddock.

All statistical analyses of infiltration rates are reported on log transformed data for this study. However, non-transformed adjusted means for infiltration rates are shown on graphs and tables to facilitate comprehension. Standard diagnostic tests on all models used did not reveal any gross violations of statistical assumptions.

\section{Lab Analysis}

The wet sieve method was used to measure aggregate stability for a more detailed assessment of the soil structure (Kemper and Rosenau 1986). Determination of both bulk density and gravimetric soil water content were made from the same sample

Table 1. Means $(\overline{\mathbf{x}})$ and standard errors (SE) for infiltration rates $(\mathrm{cm} / \mathrm{hr})$ as affected by grazing treatment, season and time of sampling for a montane riparian ecosystem.

\begin{tabular}{|c|c|c|c|c|}
\hline \multirow{3}{*}{ Time of sampling } & \multicolumn{2}{|c|}{ Spring } & \multicolumn{2}{|c|}{ Summer } \\
\hline & Grazed & Control & Grazed & Control \\
\hline & $\bar{x} \pm S E$ & $\bar{x} \pm S E$ & $\bar{x} \pm \mathrm{SE}$ & $\bar{x} \pm S E$ \\
\hline & & $-----(c 1$ & ---------. & ---- \\
\hline Before grazing & $1.1 \pm 0.3$ & $2.2 \pm 0.3$ & $3.1 \pm 0.3$ & $5.3 \pm 0.3$ \\
\hline After grazing & $0.5 \pm 0.4$ & $2.4 \pm 0.3$ & $0.6 \pm 0.3$ & $3.1 \pm 0.3$ \\
\hline 2 wk recovery & $0.4 \pm 0.3$ & $2.3 \pm 0.3$ & $0.6 \pm 0.2$ & $1.5 \pm 0.4$ \\
\hline 4 wk recovery & $0.6 \pm 0.3$ & $4.0 \pm 0.3$ & $0.7 \pm 0.2$ & $1.4 \pm 0.3$ \\
\hline $1 \mathrm{yr}$ recovery & $1.4 \pm 0.3$ & $3.7 \pm 0.2$ & $1.3 \pm 0.3$ & $2.7 \pm 0.3$ \\
\hline
\end{tabular}

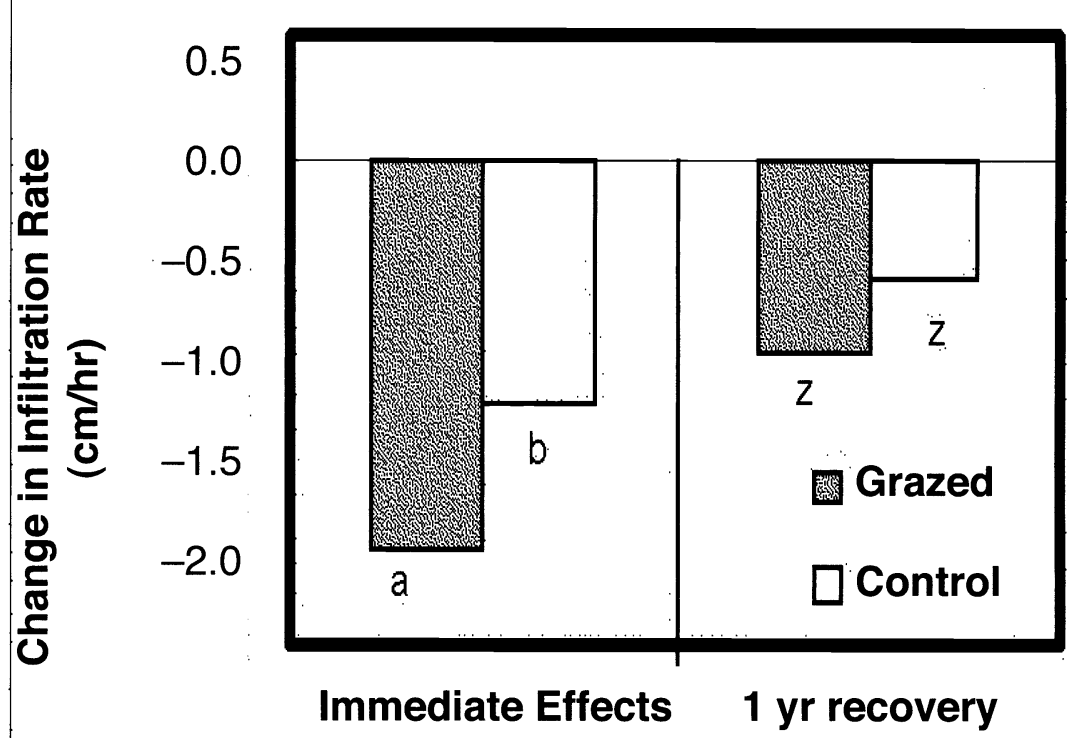

Fig. 1. Immediate effects of grazing and recovery on infiltration rates following a heavy grazing event in a montane riparian community. Different letters at the beginning of the alphabet represent statistical differences $(p<0.10)$ for immediate effects, whereas different letters at the end of the alphabet represent statistical differences $(p<0.10)$ in recovery after 1 year between grazed and control plots.

by the method outlined by Gardner (1986). Porosity was derived from particle density and bulk density as outlined by Danielson and Sutherland (1986). Soil organic C and $\mathrm{N}$ were determined by dry combustion (LECO 1993), and soil texture was assessed by the hydrometer method (Gee and Bauder 1986).

\section{Results and Discussion}

\section{Infiltration}

Infiltration rates ranged from $0.4 \mathrm{~cm} \mathrm{hr}^{-1}$ to $13.1 \mathrm{~cm} \mathrm{hr}^{-1}$. Means of infiltration rates are shown in Table 1. The high variance in infiltration data was caused an abnormal distribution of residual errors. Large variability in soil, vegetation and hydrologic

characteristics is typical of data found both within and between riparian ecosystems (Swanson 1989, Clary 1995). Therefore, all infiltration data were $\log$ transformed to meet statistical assumptions of ANOVA and multiple regression.

\section{Immediate Effects of Grazing}

Analysis of variance was used to examine the differences in mean final infiltration rates before grazing and immediately after grazing. A significant grazing treatment effect $(p=0.03)$, and a seasonal effect of grazing ( $p=0.10$ ) was found, but not an interaction effect of season of grazing (spring vs. summer) $x$ grazing treatment (grazed vs. ungrazed). Grazed plots had approximately a $1.6 \mathrm{~cm} \mathrm{hr}^{-1}$ decrease in final infiltration rates immediately after grazing, whereas final infiltration rates in control plots declined by only about 1.0 $\mathrm{cm} \mathrm{hr}{ }^{-1}$ during the same time period (Fig. 1). Soils were wetter in the summer $(74 \%$ gravimetric water content) when compared to the spring (59\% gravimetric water content) in this study, and greater reductions in infiltration rates as a result of wetter soils in the summer were found.

\section{Longer Term Effects and Recovery of Soil Properties}

Analysis of covariance, which adjusted the final infiltration rates for the last 4 


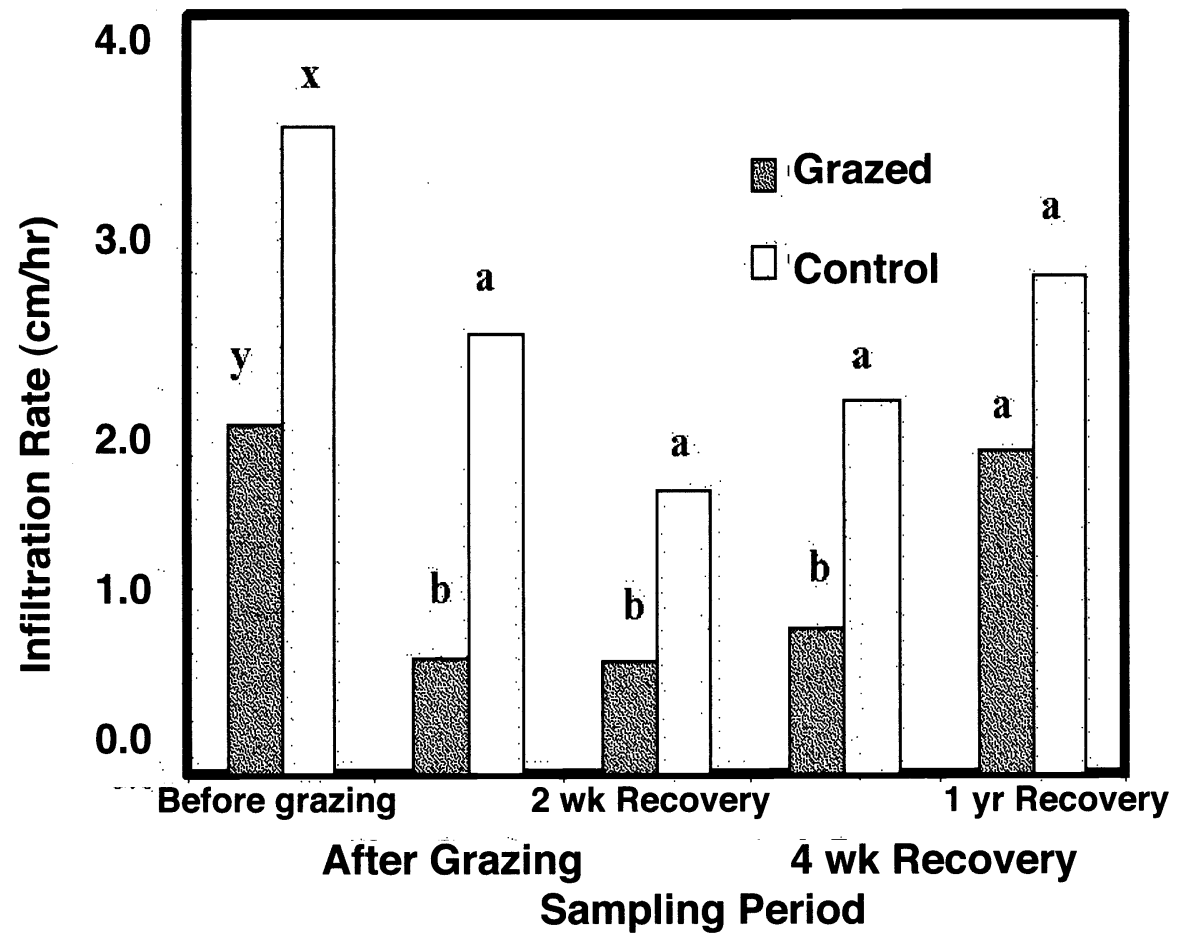

Fig. 2. Infiltration rates in grazed plots vs. control plots from immediately after grazing until 1 year later, when recovery of pre-disturbance infiltration rates were observed. Different letters above the bars represent statistical differences $(p<0.05)$ between grazed and control plots within each time period. Different letters at the end of the alphabet represent statistical differences $(p<0.05)$ between grazed and control plots before grazing was introduced.

time periods with pre-disturbance infiltration rates, yielded a significant grazing treatment (grazed vs. control) effect $(\mathrm{p}=$ $0.03)$, a significant season of grazing (spring vs. summer) effect ( $p=0.08)$, and a significant time of sampling effect ( $p<$ $0.01)$. Interactions of season of grazing or grazing treatment with sampling periods did not significantly affect the final infiltration rates.

After adjusting for differences in pretreatment infiltration rates, significant grazing treatment effects were seen in the average final infiltration rate of $0.6 \mathrm{~cm} \mathrm{hr}^{-1}$ for grazed plots after the grazing event, as compared with the average infiltration rate for ungrazed control plots of $2.7 \mathrm{~cm} \mathrm{hr}^{-1}$ (Fig. 2). Grazed plots continued to have lower infiltration rates than control plots throughout the study until 1 year after the grazing event, which signified hydrologic recovery within a year.

Seasonal changes in water table depth along streams are inevitable, as well as overland and underground flow as a result of seasonal fluvial patterns and precipitation events (Mitsch and Gosselink 1986). These hydrologic changes influence the water content of soils adjacent to the stream (Kramer 1983), which in turn affect infiltration rates, bulk density, and plant growth. Interactions between livestock use and seasonal variations in soil conditions (Warren et al. 1986a) can further cause changes in soil hydrological properties following intensive grazing.

The combination of changes in environmental conditions, along with releases of water from the upstream reservoir in this study, may partially explain the significance of the sampling date (time) in the infiltration ANOVA model. The variable nature of the riparian zone was reflected in a relatively low multiple $R^{2}$ value $(0.31)$ in the multiple regression analysis for final infiltration rates. Although several parameters are normally effective in prediction of infiltration rates, no single parameter in the model explained more than $8 \%$ of the variability in infiltration rates. Amount of clay in the top $5 \mathrm{~cm}$, moisture at the $5-10$ $\mathrm{cm}$ depth, and bulk density at the $5-10 \mathrm{~cm}$ depth were the strongest predictors of infiltration rate, but together only accounted for $23 \%$ of the variability in the final infiltration rates.

Other studies have demonstrated interactions of soil moisture, plant growth, and hydrological recovery. Warren et al. (1986a) found evidence of some hydrological recovery 56 days after grazing during the growing season, but not after the same period of rest after grazing in a drier season. Bohn and Buckhouse (1985) found a trend of hydrological recovery in a riparian community in Oregon over a 5-year period in excluded areas. The quantitative evidence for hydrological recovery within 1 year after a heavy grazing event in this riparian ecosystem is significant new information.

Abundant soil moisture and high-seral vegetation at a study site may stimulate active root growth. In addition, freezethaw action in the soils during fall and spring aid in restoring native soil characteristics (Gamougoun et al. 1984). Moreover, sedges are thought to be especially resistant to grazing because of their rhizomatous growth habit. The impressive growth rate of Carex spp. in this fertile system after grazing (personal observation) should provide an abundance of macropores (Manning et al. 1989). The interaction of vegetation with the macropore network (Logue and Gander 1986, Naeth et al. 1991) is important for maintaining infiltration rates, yet there has been little quantitative information on these interactions.

Studies have been conducted to determine relationships between various soil moisture conditions and soil hydraulic properties after grazing (Edmond 1962, Warren et al. 1986b). It is believed that there is a greater chance for compaction in wet soils than in dry soils. Infiltration rates in the spring season averaged $1.8 \mathrm{~cm} \mathrm{hr}^{-1}$ at the Sheep Creek site, whereas infiltration rates were about one half of this in the summer season $\left(0.9 \mathrm{~cm} \mathrm{hr}^{-1}\right)$. This is consistent with significantly lower gravimetric water content in the spring $(59 \%)$ than in the summer (74\%). Although soils were wetter in the summer, infiltration rates were not significantly affected by the difference in moisture, as evidenced by the lack of significant interactions between season of grazing and grazing treatment in the ANOVA model.

Confirming or refuting the interpretation that wet soils are more likely to exhibit compaction was an objective of this study. However, because of high soil moisture from a record wet year and water releases from an upstream reservoir, differences in soil moisture between spring and summer were not great enough to see a significant difference in compaction or a reduction in infiltration, and did not allow for any explicit conclusions to be drawn about wet vs. dry soil effects. 

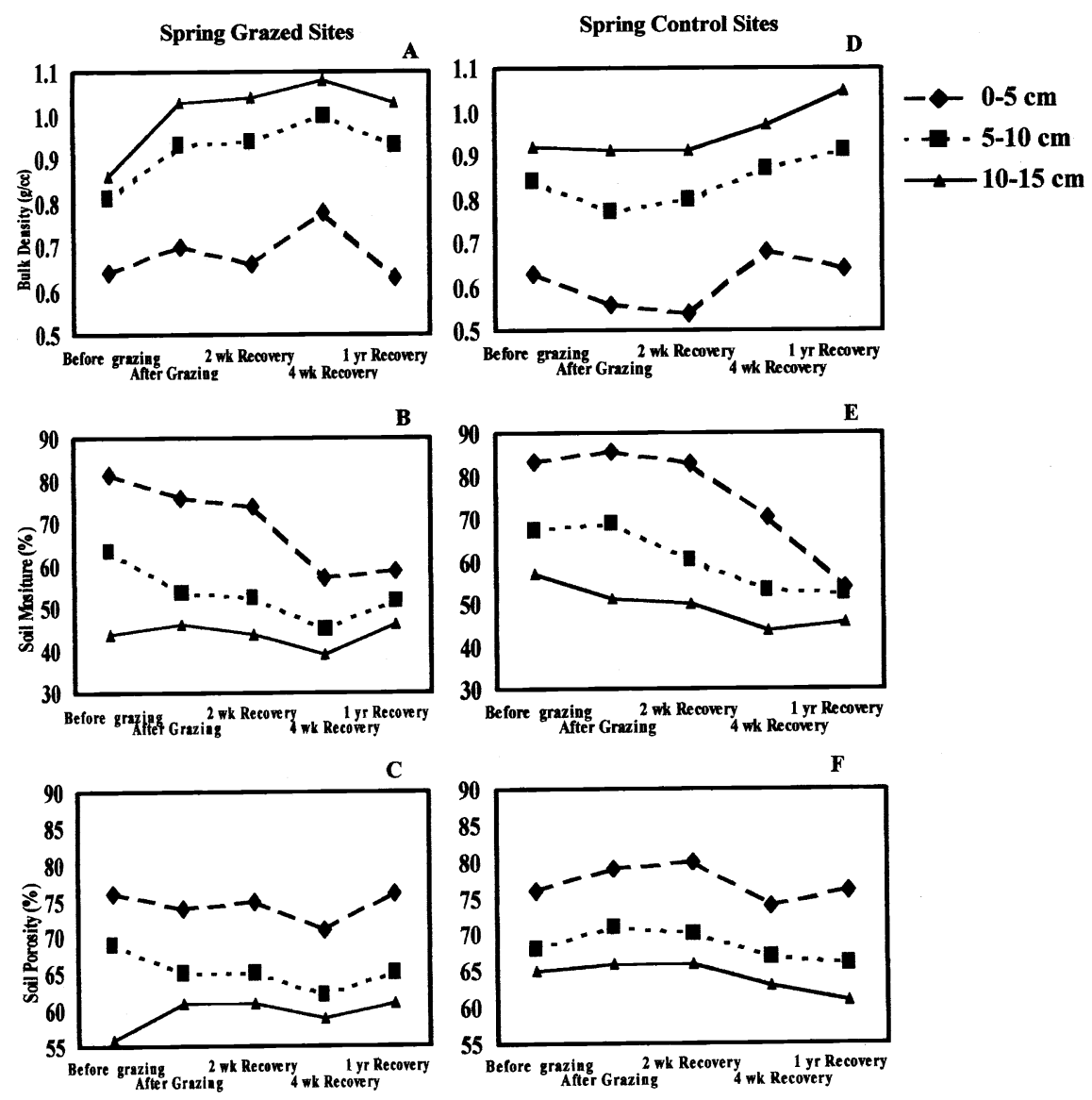

Sampling Period

Fig. 3 Trends in soil bulk density $(A, D)$, moisture $(B, E)$, and porosity $(C, F)$ for spring grazed and control paddocks at 5 sampling periods.

\section{Bulk Density and Porosity}

High organic matter contents in the surface layers within these Carex spp. communities resulted in low bulk density values. For the 3 soil depths sampled, mean values ranged from $0.60 \mathrm{~g} \mathrm{~cm}^{-3}$ for the surface layer $(0-5 \mathrm{~cm})$ to $0.91 \mathrm{~g} \mathrm{~cm}^{-3}$ for the 10-15 cm depth. Cooper et al. (1995) found similar values for bulk density in the top layer of an organic soil in New Zealand. Naeth et al. (1991) showed that some soil mixtures of organic matter and litter had water holding capacities as much as $216 \%$ of their dry weight. Figures 3 and 4 show trends in soil bulk density, porosity and moisture for both seasons of grazing and grazing treatments (grazed vs. control). Soils located deeper in the profile had greater bulk density than those closer to the surface and generally had lower water contents (Figs. 3 and 4).

A decline in soil moisture at all soil depths through the spring season was noted (Fig. 3). However, soil moisture remained high through the summer season as a result of upstream water release from Eaton Reservoir, which caused water to flow from Sheep Creek into the stream banks (Fig. 4). Greater soil moisture during the summer was reflected in bulk density and porosity values. As soil moisture increased, bulk density declined and porosity increased. Regression analysis consistently revealed a significant negative correlation $(p<0.01)$ between bulk density and soil moisture in each of the soil depths sampled. As the soil became saturated, it expanded the organic matter which resulted in lower bulk density.

Given the unusually heavy dependence of bulk density on soil moisture found in this study, the average gravimetric water content in the spring (59\%) compared with summer $(74 \%)$ translated into higher average bulk density values in the spring $(0.84$ $\left.\mathrm{g} \mathrm{cm}^{-3}\right)$ as compared with the summer $\left(0.70 \mathrm{~g} \mathrm{~cm}^{-3}\right)$. Porosity was inversely related to bulk density and was significantly higher in the summer $(74 \%)$ than in the spring $(68 \%)$.

\section{Immediate Effect of Grazing}

Increased soil bulk density and decreased porosity immediately after the grazing event are shown in Figures 3a, 3c, $4 \mathrm{a}$ and $4 \mathrm{c}$. Bulk density was significantly increased immediately after grazing at the $5-10 \mathrm{~cm}$ soil depth $(p=0.04)$ and the $10-15 \mathrm{~cm}$ depth $(\mathrm{p}=0.07)$, but not in the top $5 \mathrm{~cm}(\mathrm{p}=0.11)$. Average bulk density increased $0.09 \mathrm{~g} \mathrm{~cm}^{-3}$ at $5-10 \mathrm{~cm}$, and 0.11 $\mathrm{g} \mathrm{cm}^{-3}$ at the $10-15 \mathrm{~cm}$ depth (Fig. 5). Cattle trampling on the highly organic surface layer caused water to be forced from the expansive organic soil, but this organic layer probably rehydrated within minutes given the extremely wet conditions of the sites. The highly organic top layer may also dissipate the force of cattle hooves on the soil surface that should result in less compaction of the soil underneath. However, even in this near pristine community, the soil under the organic layer showed evidence of compaction immediately after grazing (Fig. 5). Protection of lower soil depths by the organic surface layer may be significant, but further work should be done to determine the amount of organic matter needed to serve this purpose. No significant interactions in bulk density as affected by season of grazing (spring vs. summer) $\mathrm{x}$ grazing treatment (grazed vs. control) were detected for any of the soil depths sampled, which again showed that the effects of the grazing treatments were similar, regardless of season of grazing. Opposite trends were seen in soil porosity values as compared with bulk density data. Porosity decreased significantly at the $5-10 \mathrm{~cm}$ and $10-15 \mathrm{~cm}$ depths after grazing ( $\mathrm{p}=0.05$ and 0.08 , respectively) in grazed plots and increased slightly in control plots. The reduction in soil porosity within grazed paddocks was an effect of cattle trampling that reduced pore space.

Although porosity is a good measure of total pore space, a measure of changes in pore size distribution would have been more helpful to assess changes in the distribution of macropores. Macropores are considered the dominant force behind vertical flow in soil (Beven and Germann 1982). Studies have shown that trampling by livestock can destroy the large macropores that conduct large volumes of water into the soil profile (Dreccer and Lavado 1993). Methods used in this study to evaluate aggregate stability and thus indirectly pore size distribution were inconclusive because of the high interaction of soil properties with vegetation. The role of plant roots in binding soil aggregates could not be assessed by the wet sieve method, although the interaction of the riparian vegetation with soil stabilization 

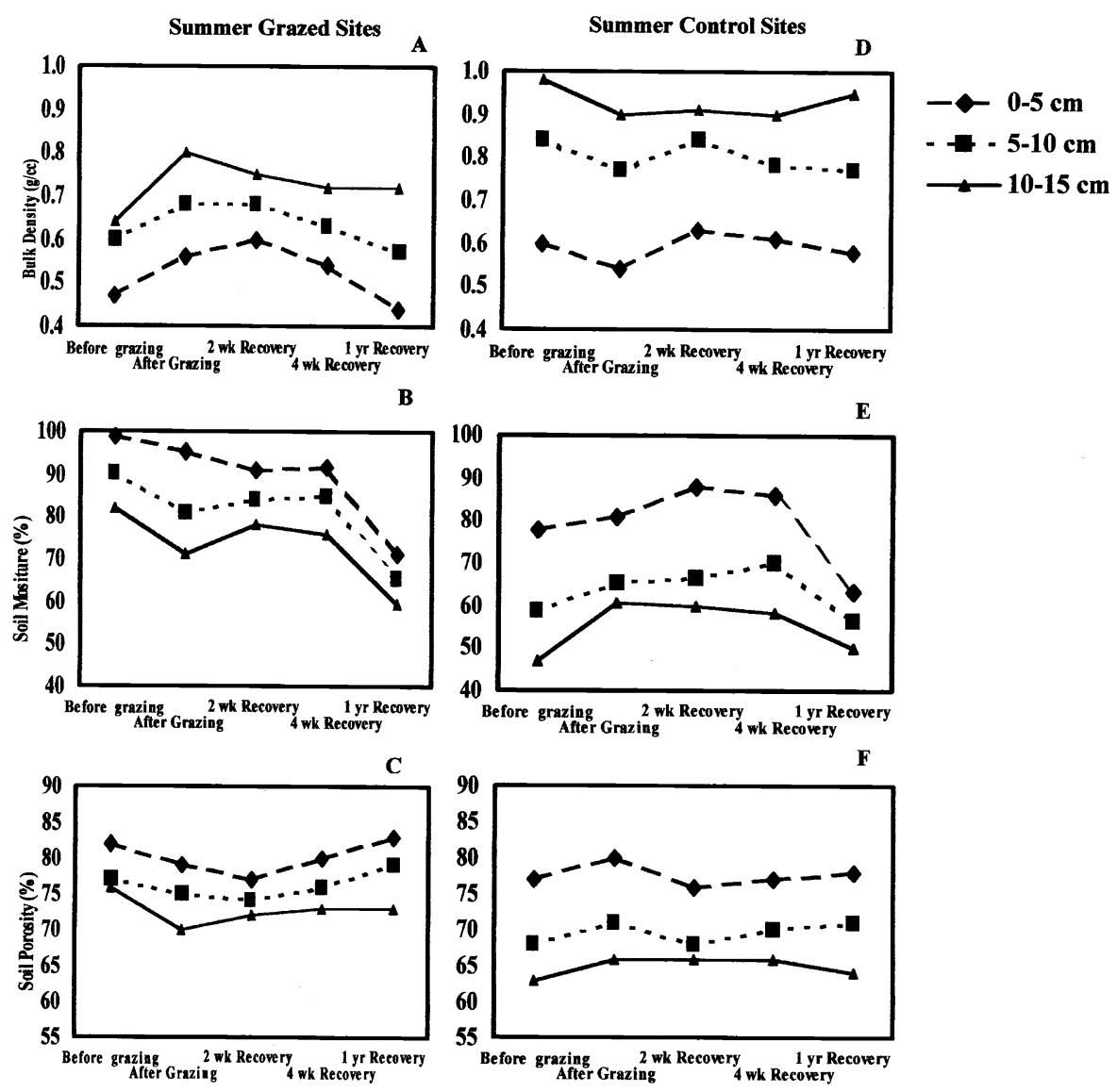

Sampling Period

Fig. 4. Trends in soil bulk density (A,D), moisture (B,E), and porosity $(C, F)$ for summer grazed and control paddocks at 5 sampling periods.

is a primary mechanism for bank stability (Swanson 1989). New methods for the quantification of pore size distribution and the role of roots in binding riparian soils are needed.

\section{Longer Term Effects and Recovery of Soil Properties}

An ANOVA model for bulk density was used for all statistical comparisons for long term grazing effects and recovery of bulk density. Analysis of bulk density data for the last 4 time periods revealed no evidence for a significant grazing treatment effect. A significant season of grazing $X$ time of sample collection interaction for the $0-5 \mathrm{~cm}$ and $5-10 \mathrm{~cm}$ soil depths $(\mathrm{p}=$ 0.03 and 0.04 , respectively), was most likely caused by changes in soil moisture. Differences in soil moisture between spring and late summer were also a probable cause for the significant season of grazing effect for the $5-10 \mathrm{~cm}$ soil depth. The significant grazing treatment $\mathrm{x}$ time of sample collection effect observed for the $0-5 \mathrm{~cm}$ depth was largely caused by a decrease in bulk density after 1 year of recovery, possibly caused by freezing and thawing activity during this period. Bulk density values in grazed and ungrazed paddocks showed no significant differences caused by grazing treatment, season of grazing, or grazing treatment $\mathrm{x}$ season interaction for any of the depths sampled 1 year after the grazing event (Fig. 5).

The spatial and temporal variability of soil properties in these ecosystems is difficult to capture accurately because of interactions with vegetation and hydrology (Krueper 1992). Future studies should include simultaneous quantification of hydrological characteristics such as water table depth and stream flow patterns and infiltration rates in distinct plant communities. Since infiltration is often augmented by root channels (Manning et al. 1989), different rooting systems may influence infiltration rates. Cattle have been shown to step preferably in the interspace between vegetation tussocks (Balph and Malechek 1985), it would be helpful to quantify the respective infiltration rates over crowns of vegetation as opposed to interspaces between vegetation tussocks, and how each of these are affected by grazing.

It may be possible to calculate grazing impacts and recovery rates of riparian areas with the use of quantitative assessment of initial characteristics of hydrology, soil characteristics and vegetation cover and production. If potential impacts and recovery rates are known, sustainable grazing regimes in riparian zones can be more accurately predicted.

\section{Conclusions}

This study showed the potential of a riparian zone to recover hydrologically from a heavy grazing event. The physical conditions present at the site, (namely abundant soil moisture, active vegetative growth, and abundant organic matter in the soil) facilitates recovery to pre-disturbance soil physical properties within 1 year after a heavy grazing event. However, the study area had not been grazed by livestock since 1956, so the conditions prior to grazing were near pristine in terms of vegetation composition and cover. This unique situation should be kept in mind when considering the time needed for other riparian zones to recover from grazing practices. Interactions of abiotic and biotic processes within a riparian zone are tightly linked, and separation of these processes is extremely complex. Hydrology and geomorphology greatly influence sediment movement, sediment deposition, soil development and plant community succession. These characteristics in turn influence soil physical characteristics that are important for a functional hydrologic regime. Initial hydrological, soil and vegetation conditions of the riparian zone should be considered when recommendations for length of rest periods after grazing are to be made. This should result in a better assessment of interactions among various processes that operate within the riparian zone and how they might be affected by grazing.

The thick organic layer present in the surface soil in this system may have provided a protective layer against compaction at the soil surface. Oades (1984) suggested management of organic matter to maintain soil structure for water infiltration, active root growth and soil stabilization for dryland agriculture. A similar approach could be taken for riparian zones. Organic matter played an important role in the maintenance of soil physical properties in this riparian zone. Further 


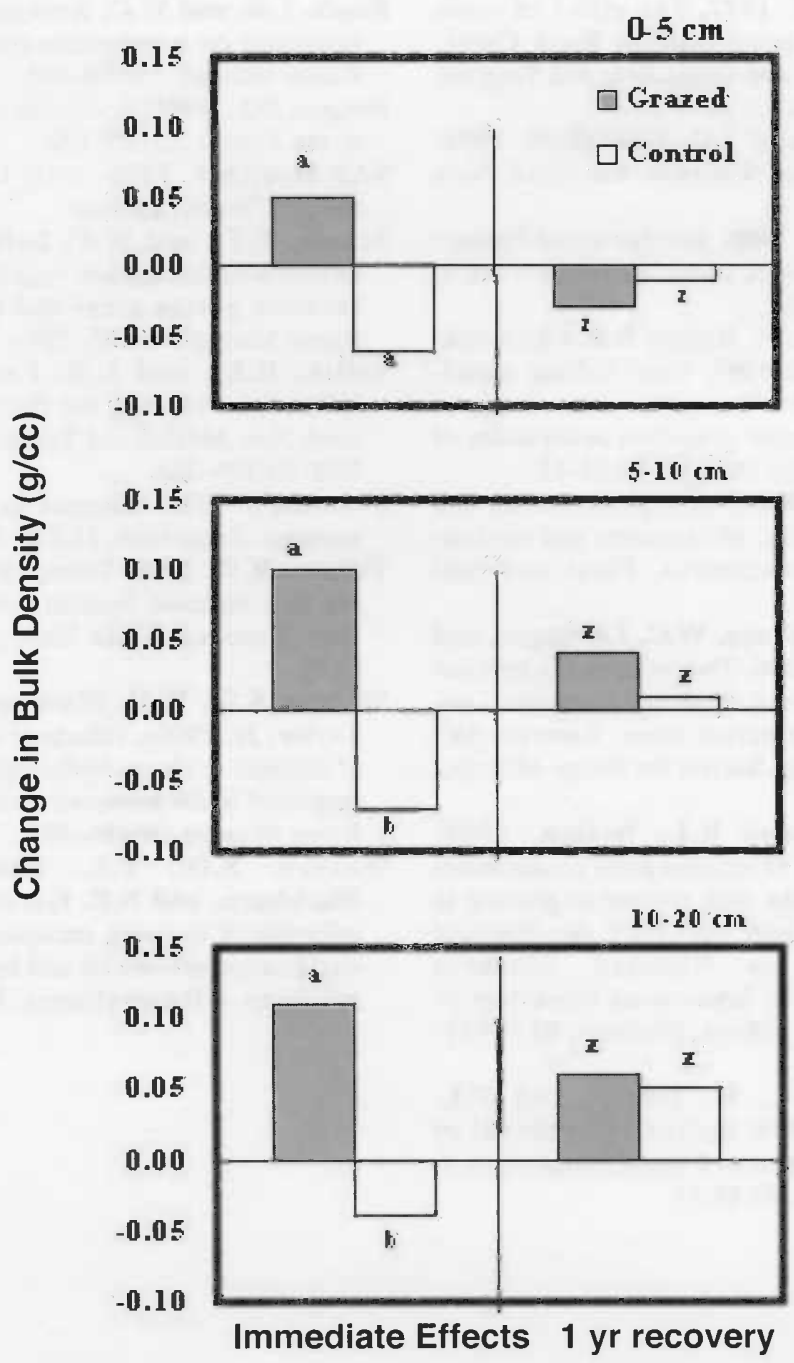

Fig. 5. Immediate effects and recovery of bulk density at 3 soil depths following a heavy grazing event in a montane riparian community. Different letters above and below bars at the beginning of the alphabet represent statistical differences $(p<0.10)$ in immediate effects. Different letters at the end of the alphabet represent statistical differences $(p<0.10)$ in recovery.

work should be conducted to determine the amount of organic matter needed in riparian soils to maintain desired soil physical properties, particularly for annually repeated grazing use.

\section{Literature Cited}

Abdel-Magid, A.H., G.E. Schuman, and R.H. Hart. 1987a. Soil bulk density and water infiltration as affected by grazing systems. J. Range Manage. 40:307-309.

Abdel-Magid, A.H., M.J. Trlica, and R.H. Hart. 1987b. Soil and vegetation responses to simulated trampling. J. Range Manage. 40:303-306.
Armour, C., D. Duff, and W. Elmore. 1994. The effects of livestock grazing on western riparian and stream ecosystem. Fisheries 19:9-12.

Balph, D.F. and J.C. Malechek. 1985. Cattle trampling of crested wheatgrass under shortduration grazing. J. Range Manage. $38: 226-227$.

Beven, K. and P. Germann. 1982. Macropores and water flow in soils. Water Resour. Res. 18:1311-1325.

Blake, G.R. and K.H. Hartge. 1986. Bulk density. pp. 363-375. In: A. Klute (ed.) Methods of Soil Analysis, Part 1, $2^{\text {nd }}$ ed. Amer. Soc. Agron. Madison, Wis.

Bohn, C.C. and J.C. Buckhouse. 1985. Some responses of riparian soils to grazing management in northeastern Oregon. J. Range Manage. 38:378-381.
Bouwer, H. 1986. Intake rate: cylinder infiltrometer. pp. 825-844. In: A. Klute (ed.) Methods of Soil Analysis, Part 1, $2^{\text {nd }}$ ed., Amer. Soc. Agron. Madison, Wis.

Branson, F.A., G.F. Gifford, K.G. Renard, and R.F. Hadley. 1981. Rangeland Hydrology. 2nd ed. Kendall/Hunt Pub. Co. Dubuque, Iowa.

Bryant, H.T., R.E. Blaser, and J.R. Peterson. 1972. Effect of trampling by cattle on bluegrass yield and soil compaction of a meadowville loam. Agron. J. 64:331-334.

Chaney, E., W. Elmore, and W.S. Platts. 1990. Livestock grazing on western riparian areas. U.S. Gov. Print. Off. 1990- 775443/21, 661 Region No. 8, Wash. D.C. 45 p.

Clary, W.P. 1995. Vegetation and soil responses to grazing simulation on riparian meadows. J. Range Manage. 48:18-25.

Cooper, A.B., C.M. Smith, and M.J. Smith. 1995. Effects of riparian set-aside on soil characteristics in an agricultural landscape: Implications for nutrient transport and retention. Agr. Ecosys. and Envir. 55:61-67.

Costello, D.F. 1944. Important species of the major forage types in Colorado and Wyoming. Ecol. Mono. 14:106-134.

Dadkhah, M. and G.F. Gifford. 1980. Influence of vegetation, rock cover, and trampling on infiltration rates and sediment production. Water Resour. Bull. 16:979-986.

Danielson, C.H. and D.B. Sutherland. 1986. Porosity. pp. 587-590. In: Klute (ed.) Methods of Soil Analysis, Part 1, $2^{\text {nd }}$ ed. Amer. Soc. Agron. Madison, Wis.

Dreccer, M.F., and R.S. Lavado. 1993. Influence of cattle trampling on preferential flow paths in alkaline soils. Soil Use and Manage. 9:143-148.

Edmond, D.B. 1962. The influence of treading on pasture: A preliminary study. N.Z. J. Agr. Res. 1:319-328.

Gamougoun, N.D., R.P. Smith, M.K. Wood, and R.D. Pieper. 1984. Soil, vegetation, and hydrologic responses to grazing management at Fort Stanton, New Mexico. J. Range Manage. 37:538-541.

Gardner, W.H. 1986. Water content pp.493-544. In: A. Klute (ed.) Methods of Soil Analysis, Part 1, 2nd ed. Amer. Soc. Agron. Madison, Wis.

Gee, G.W. and J.W. Bauder. 1986. Particle size analysis. pp. 383-399. In: A. Klute (ed.) Methods of Soil Analysis, Part 1, 2nd ed. Amer. Soc. Agron. Madison, Wis.

Gifford, G.F. and R.H. Hawkins. 1978. Hydrologic impact of grazing on infiltration: A critical review. Water Resour. Res. 14:305-315.

Gregory, S.V., F.J. Swanson, W.A. McKee, and K.W. Cummins. 1991. An ecosystem perspective of riparian zones. BioScience 41:540-551.

Hawk, G.M. and D.B. Zobel. 1974. Forest succession on alluvial landforms of the McKenzie River valley, Oregon. Northwest Sci. 48:245-265. 
Kemper, W. and R.C. Rosenau. 1986. Aggregate stability and size distribution. pp. 425-442. In: A. Klute (ed.) Methods of Soil Analysis, Part 1, $2^{\text {nd }}$ ed. Amer. Soc. Agron. Madison, Wis.

Kramer, P.J. 1983. Water Relations of Plants. Academic Press, New York.

Krueper, D.L. 1992. Effects of land use practices in western riparian ecosystems. pp. 321-330. In: D.M. Finch and P.W. Stangel (eds.) Status and Management of Neotropical Migratory Birds. Proc. of a Workshop. Estes Park, Colo. Sept. 21-25, 1990.

Johnson, R.R., C.D. Ziebell, D.R. Patton, P.F. Ffolliott, and R.H. Harme (tech. coords.) 1985. Riparian Ecosystems and Their Management: Reconciling Conflicting Uses. First North American Riparian Conference. April 16-18, 1985, Tuscon, Ariz. U.S.D.A. For. Serv., Gen. Tech. Rept. RM-120.

LECO Corporation. 1993. Instruction Manual CHN-1000 Elemental Analyzer. Form No. 200-516-014. Leco Corp., St. Joseph, Mich.

Leininger, W.C. and M.J. Trlica. 1986. Grazing impacts to a northcentral Colorado riparian zone. p. $214 \mathrm{In}$ : Abstracts of IV Inter. Cong. Ecol., Syracuse, N.Y.

Logue, K. and G.A. Gander. 1986. R-5 Revisited: 1 . Spatial variability of infiltration on a small rangeland catchment. Water Resour. Res. 26:957-971.

Manning, M.E., S.R. Swanson, T. Svejcar, and J. Trent. 1989. Rooting characteristics of four intermountain meadow community types. J. Range Manage. 42:309-312.
Marcuson, P.E. 1977. The effect of cattle grazing on brown trout in Rock Creek, Montana. Fish and Game Fed. Aid Program. F-20-R-21-11a.

Mitsch, W.J. and J.G. Gosselink. 1986. Wetlands. Van Nostrand Reinhold, New York.

Moreland, D.C. 1980. Soil Survey of Larimer County Area, Colorado. USDA-SCS, Washington, D.C.

Naeth, M.A., A.W. Bailey, D.S. Chanasyk, and D.J. Pluth. 1991. Water holding capacity of litter and soil organic matter in mixed prairie and fescue grassland ecosystems of Alberta. J. Range Manage. 44:13-17.

Oades, J.M. 1984. Soil organic matter and strutural stability: Mechanisms and implications for management. Plant and Soil 76:319-337.

Pelster, A., S. Evans, W.C. Leininger, and W.P. Clary. 1996. The relationship between diet preferences of steers and herbaceous utilization in a riparian zone. Abstract $49^{\text {th }}$ Annual Meeting. Society for Range Manage., Wichita, Kans

Platts, W.S. and R.L. Nelson. 1989. Characteristics of riparian plant communities and streambanks with respect to grazing in northeastern Utah. pp.73-85. In: Practical Approaches to Riparian Resource Management: An Educational Workshop, 811 May 1989, Billings, Montana. BLM-MTPT-89-001-4351.

Popolizio, C.A., H. Goetz, and P.L. Chapman. 1994. Short-term response of riparian vegetation to 4 grazing treatments. J. Range Manage. 47:48-53.
Roath, L.R. and W.C. Krueger. 1982. Cattle influence on a mountain riparian zone. J. Range Manage. 35:100-104.

Rosgen, D.L. 1994. A classification of natural rivers. Catena 22:169-199.

SAS Institute. 1996. SAS User's Guide. Raleigh, North Carolina.

Schulz, T.T., and W.C. Leininger. 1990. Differences in riparian vegetation structure between grazed areas and exclosures. J. Range Manage. 43:295-299.

Smith, H.L., and L.B. Leopold. 1941. Infiltration studies in the Pecos River watershed, New Mexico and Texas. Water Resour. Bull. 23:195-204.

Swanson, S. 1989. Priorities for riparian management. Rangelands 11:228-230.

Tierney, R.W. 1992. Transpiration and water use in a montane riparian ecosystem. Ph.D. Diss. Colorado State Univ., Fort Collins, Colo.

Warren, S.D., W.H. Blackburn, and C.A. Taylor, Jr. 1986a. Effects of season of stage of rotation cycle on hydrologic condition of rangeland under intensive rotation grazing. $\mathrm{J}$. Range Manage. 39:486-491.

Warren, S.D., T.L. Thurow, W.H. Blackburn, and N.E. Garza. 1986b. The influence of livestock trampling under intensive rotation grazing on soil hydrologic characteristics. J. Range Manage. 39:491-495. 